\title{
In Vitro Methane Production Potential, Nutrient Digestibility and Fermentation Pattern of Total Mixed Rations containing Incremental Levels of Novel Feedstuff - Phalaris minor Seeds in Buffalo Inoculum
}

\author{
Jasmine Kaur* and Sudarshan Singh Thakur \\ Dairy Cattle Nutrition Division, ICAR-National Dairy Research Institute, Karnal, India \\ *Corresponding author
}

\section{A B S T R A C T}

\begin{tabular}{|l|}
\hline K e y w o r d s \\
Total mixed ration, \\
In vitro \\
digestibility, \\
Fermentation, \\
Phalaris minor \\
seeds. \\
\hline Article Info \\
\hline $\begin{array}{l}\text { Accepted: } \\
\text { 04 July } 2017 \\
\text { Available Online: } \\
\text { 10 September } 2017\end{array}$ \\
\hline
\end{tabular}

\section{Introduction}

India has the highest livestock's population in the world and the country is also the highest milk producer, but is facing a major green fodder crisis in absence of adequate grassland due to growing pressure of population on land. In 1947, the country had 70 million hectares under grassland which is now reduced to 38 million hectares. India may have to import milk in four years, if it cannot increase fodder supply, as rising pressure on land is reducing pastures nationwide. To boost milk yield, India would need to generate 1,764 million tonnes of fodder by 2020, according to an India Spend analysis of government data. But existing sources can only manage about 900 million tonnes of fodder. Currently, feed and fodder are in short supply to the tune of $63 \%$ green fodder, $24 \%$ dry fodder and $76 \%$ concentrates. Only $4 \%$ of total cultivable land in India is used for fodder 
production, a proportion that has remained stagnant for the last four decades (Patil, 2017). Thus, to meet the nutrient requirements of animals, we need to improve either the efficiency of utilization of already existing feed ingredients/nutrients or need to tap new non-conventional feed resources.

Phalaris minor is one such non-conventional feedstuff. It is an annual fast spreading weed in the entire north-western belt of India, where rice-wheat cropping system is followed. P. minor belongs to Graminae family. It is commonly known as Gulli Danda, Mandusi and Gehunka Mama. Its seeds are widely available from fields in Punjab, Haryana, Uttar Pradesh, Madhya Pradesh, parts of Bihar and Himachal Pradesh. The present work examines the effect of replacement of maize grains with $P$. minor seeds in the total mixed ration (TMR) at graded levels on in vitro nutrient digestibility, methane production and rumen fermentation pattern in buffalo inoculum.

\section{Materials and Methods}

\section{Sample collection and preparation}

Samples of common energy feeds fed to livestock, viz. maize (Zea mays), wheat (Triticum aestivum), pearl millet (Pennisetum typhoides), barley (Hordeum vulgare) and unconventional energy supplement, viz. Phalaris minor seeds were collected from various places (Farm section of National Dairy Research Institute, Karnal and local market, Karnal). The samples were dried in hot air oven $\left(60^{\circ} \mathrm{C}, 24 \mathrm{~h}\right)$ and ground to pass through $1.0 \mathrm{~mm}$ sieve. Grounded samples were stored in plastic containers for chemical estimations. Maize based conventional concentrate mixture containing maize grains 38 , mustard cake 10 , groundnut cake 23 , deoiled rice bran 6 , wheat bran 20 , mineral mixture 2 and common salt 1 part each was prepared. Maize grains in the conventional concentrate mixture were replaced by $P$. minor seeds at graded levels of 25, 50, 75 and 100 per cent on w/w basis. Maize based concentrate mixtures were then mixed with oven dried oatfodder and wheat strawin 40:40:20 ratio, respectively to formulate five TMRs. The roughage to concentrate ratio of TMR was kept at 60:40.

\section{Proximate and cell wall constituents}

Energy feeds and TMRs were analysed for dry matter (DM), Kjeldahl N, ether extract (EE) and ash content using the standard procedures (AOAC, 2005). Crude protein (CP) content of samples was determined as Kjeldahl $\mathrm{N} \times 6.25$ by digesting in sulphuric acid and digestion mixture (consisting of sodium/potassium sulphate and copper sulphate in 10:1 ratio) using semiautoanalyser (Kel plus Classic-DX, Pelican). Cell wall fractions, viz. NDF, ADF, cellulose and lignin were estimated sequentially using the standard procedure (Van Soest et al., 1991). NDF and ADF were expressed inclusive of residual ash. Lignin was determinedbysolublizationofcellulosewith72 per cent sulphuric acid.

\section{In vitro evaluation}

The nutritional worth of various TMRs formulated was assessed by in vitro gas production technique (Menke et al., 1979; Menke and Steingass, 1988). Rumen contents were collected from fistulated adult male buffalofed concentrate mixture (maize 32, groundnut cake 25 , wheat bran 40 , mineral mixture 2 and salt 1 part each), wheat straw and chopped green oat fodder as per the requirements (ICAR, 2013).Two sets of samples were incubated in triplicates. In the $\mathrm{I}^{\text {st }}$ set, about $375 \mathrm{mg}$ of the ground sample (dry matter basis) was incubated at $39^{\circ} \mathrm{C}$ for $24 \mathrm{~h}$ in triplicate in $100 \mathrm{ml}$ calibrated glass 
syringes with buffered rumen fluid for assessing the net gas production, digestibility of nutrients, total volatile fatty acid (TVFA) production (Barnett and Reid, 1957) and metabolizable energy (ME) availability. Individual volatile fatty acids were determined by using GLC equipped with a glass column (6 ft length and 1/8 inch diameter) packed with chromosorb 101. Samples were prepared by adding $0.2 \mathrm{ml}$ of $25 \%$ metaphosphoric acid per $\mathrm{ml}$ of rumen liquor, allowing it to stand for $2 \mathrm{~h}$ followed by centrifugation at $4000 \mathrm{rpm}$ for $7 \mathrm{~min}$. Supernatant was used for estimation of individual volatile fatty acids (IVFA).

In the $2^{\text {nd }}$ set, total gas production was recorded after $24 \mathrm{~h}$ of incubation. From the headspace of each syringe, $100 \mathrm{ml}$ gas was collected by puncturing the silicon tube and injected in gas chromatograph for the estimation of methane. Standard calibration gas (Sigma gases, New Delhi) consisted of equal proportion of methane and carbon dioxide. The flow rates for nitrogen, hydrogen and zero air were 30, 30, $320 \mathrm{ml} / \mathrm{min}$ respectively. Blank and standard hay (berseem hay) were run in triplicate with each set.

\section{Statistical analysis}

The data were subjected toone-way analysis of variance procedure of SAS (2003), using the linear model. The post-hoc comparison of means was done for the significant difference by Tukey's b. Significant differences of treatments were considered at $\mathrm{P}<0.05$ level.

\section{Results and Discussion}

\section{Chemical composition of Phalaris minor seeds and conventional energy sources}

Organic matter content in $P$. minor seeds was lower than conventional cereal grains (Table
1). This might be attributed to the higher total ash content in $P$. minor seeds. CP content of $P$. minor seeds was similar to that of wheat and was higher than other conventional cereal grains evaluated.These findings are in accordance with those of Kaur et al., (2006, 2017) and Kaur and Thakur (2016). P. minor seeds recorded highest $\mathrm{EE}$ and total ash. $P$. minor seeds had higher NDF content than maize and wheat, however, it was lower than pearl millet and barley. The hemicellulose content of $P$. minor seeds was similar to that of maize, though it was lower than pearl millet and barley.

ADF, cellulose and lignin levels were the highest in $P$. minor seeds among the energy sources evaluated. Starch content of $P$. minor seeds was similar to that of barley, but it was lower than other conventional cereal grains evaluated. The values obtained for chemical composition of conventional cereal grains were within the normal range (Ranjhan, 1998) and similar to those reported by earlier workers (Kamble et al., 2010; Lamba et al., 2014). Our findings regarding chemical constituents of $P$. minor seeds are also in close agreement with those of Gupta et al., (1989).

\section{Chemical composition of experimental total mixed rations}

The chemical composition of various TMRs formulated is presented in table 2 . The crude protein, ether extract and total ash content of TMRs increased slightly with the increasing level of $P$. minor seeds because of greater amount of protein, fat and ash in $P$. minor seeds as compared to maize grains. Similar trend was observed in total ash, NDF, ADF and ADL levels which showed increase, with increasing level of $P$. minor seeds in the TMR. The OM content decreased with increasing level of $P$. minor seeds, because of higher total ash content of $P$. minor seeds. 


\section{In vitro evaluation}

\section{Net gas production}

The net gas production from TMR 2, TMR 3 and TMR 4 containing 25, 50 and 75 per cent $P$. minor seeds in the concentrate mixture, respectively was similar to that from TMR 1 (without P. minor seeds) (Table 3).

However, the net gas production was depressed $(\mathrm{P}<0.05)$ in TMR $5(171.84 \mathrm{~L} / \mathrm{kg}$ $\mathrm{DM} / 24 \mathrm{~h})$ containing concentrate mixture where maize grains were completely replaced with $P$. minor seeds. The above findings are in close agreement with those of Kaur et al., (2006), who observed similar trend in net gas production on replacing cereal grains in the concentrate mixture with $P$. minor seeds.

\section{Methane production}

The methane production in TMRs followed a trend similar to that of net gas production (Table 3). The methane production $(\mathrm{L} / \mathrm{kg}$ $\mathrm{DM} / 24 \mathrm{~h})$ was the highest $(\mathrm{P}<0.05)$ from TMR 1 (54.58) and lowest $(\mathrm{P}<0.05)$ from TMR 5 (50.33), containing concentrate mixture with complete replacement of maize grains by $P$. minor seeds.

Table.1 Chemical composition (\% DM basis) of Phalaris minor seeds and Conventional energy sources

\begin{tabular}{lccccc}
\hline Parameter & Phalaris minor & Maize & Wheat & Pearl millet & Barley \\
\hline Organic matter & 92.46 & 98.67 & 98.77 & 98.03 & 97.53 \\
Crude protein & 12.33 & 9.03 & 12.03 & 9.40 & 10.90 \\
Ether extract & 6.27 & 4.23 & 2.00 & 3.00 & 2.10 \\
Total ash & 7.53 & 1.30 & 1.17 & 2.00 & 2.50 \\
NDF & 24.47 & 19.93 & 17.80 & 38.20 & 40.07 \\
ADF & 10.23 & 5.47 & 4.47 & 5.43 & 9.00 \\
Hemicellulose & 14.33 & 14.47 & 13.33 & 32.77 & 31.07 \\
Cellulose & 5.50 & 1.83 & 1.47 & 1.77 & 4.67 \\
ADL & 2.03 & 0.20 & 0.57 & 0.40 & 0.77 \\
Starch & 50.00 & 65.00 & 62.00 & 54.00 & 50.67 \\
\hline
\end{tabular}

$\mathrm{NDF}=$ Neutral detergent fibre; $\mathrm{ADF}=\mathrm{Acid}$ detergent fibre; $\mathrm{ADL}=\mathrm{Acid}$ detergent lignin

Table.2 Chemical composition (\% DM basis) of total mixed rations containing incremental Levels of Phalaris minor seeds

\begin{tabular}{|l|c|c|c|c|c|}
\hline \multirow{2}{*}{ Parameters } & \multicolumn{5}{|c|}{ Level of P. minor seeds in the concentrate mixture (\%) } \\
\cline { 2 - 6 } & $\mathbf{0}$ & $\mathbf{2 5}$ & $\mathbf{5 0}$ & $\mathbf{7 5}$ & $\mathbf{1 0 0}$ \\
\hline DM & 93.2 & 93.3 & 93.7 & 93.5 & 93.5 \\
\hline OM & 91.3 & 91.2 & 90.5 & 90.3 & 90.2 \\
\hline CP & 12.6 & 12.8 & 12.9 & 13.0 & 13.2 \\
\hline EE & 3.0 & 3.3 & 3.4 & 3.6 & 3.7 \\
\hline Total ash & 8.7 & 8.8 & 9.5 & 9.7 & 9.8 \\
\hline NDF & 53.5 & 54.0 & 54.5 & 54.0 & 54.5 \\
\hline ADF & 38.0 & 38.0 & 40.0 & 41.0 & 41.0 \\
\hline Hemicellulose & 15.5 & 16.0 & 14.5 & 13.0 & 13.5 \\
\hline Cellulose & 24.1 & 24.5 & 25.0 & 25.6 & 26.0 \\
\hline ADL & 4.3 & 4.5 & 4.6 & 4.8 & 4.9 \\
\hline
\end{tabular}

$\mathrm{DM}=$ Dry matter; $\mathrm{OM}=$ Organic matter; $\mathrm{CP}=\mathrm{Crude}$ protein; $\mathrm{EE}=$ Ether extract; $\mathrm{NDF}=$ Neutral detergent fibre; $\mathrm{ADF}=$ Acid detergent fibre; $\mathrm{ADL}=$ Acid detergent lignin. 
Table.3 Effect of level of Phalaris minor seeds on the in vitro gas production, methane and Digestibility of nutrients in the total mixed ration

\begin{tabular}{|l|c|c|c|c|c|}
\hline TMR & $\begin{array}{c}\text { Level of } P . \text { minor seeds in } \\
\text { concentrate mixture }(\%)\end{array}$ & $\begin{array}{c}\text { Net gas production } \\
(\mathrm{L} / \mathrm{kg} \mathrm{DM} / 24 \mathrm{~h})\end{array}$ & $\begin{array}{c}\text { Methane } \\
(\mathrm{L} / \mathrm{kg} \mathrm{DM} / 24 \mathrm{~h})\end{array}$ & IVDMD (\%) & IVOMD (\%) \\
\hline TMR-1 & 0 & $181.62^{\mathrm{b}} \pm 0.64$ & $54.58^{\mathrm{b}} \pm 0.52$ & $57.76^{\mathrm{b}} \pm 1.17$ & $64.49^{\mathrm{b}} \pm 1.10$ \\
\hline TMR-2 & 25 & $180.16^{\mathrm{b}} \pm 0.80$ & $53.78^{\mathrm{ab}} \pm 1.29$ & $56.39^{\mathrm{b}}+ \pm 0.57$ & $63.22^{\mathrm{b}} \pm 0.55$ \\
\hline TMR-3 & 50 & $178.38^{\mathrm{b}} \pm 0.85$ & $52.15^{\mathrm{ab}} \pm 0.67$ & $54.93^{\mathrm{b}} \pm 0.15$ & $62.03^{\mathrm{b}} \pm 0.37$ \\
\hline TMR-4 & 75 & $177.43^{\mathrm{b}} \pm 1.56$ & $51.24^{\mathrm{ab}} \pm 0.68$ & $54.52^{\mathrm{b}} \pm 1.20$ & $61.46^{\mathrm{b}} \pm 1.66$ \\
\hline TMR-5 & 100 & $171.84^{\mathrm{a}} \pm 0.79$ & $50.33^{\mathrm{a}} \pm 0.33$ & $48.96^{\mathrm{a}} \pm 0.93$ & $55.46^{\mathrm{a}} \pm 0.58$ \\
\hline
\end{tabular}

Means bearing different superscripts in a column differ significantly $(\mathrm{P}<0.05)$; Roughage: concentrate ratio in TMR 1, TMR 2, TMR 3, TMR 4 and TMR 5 was 60:40 on DM basis; All the 5 TMRs contained oats fodder and wheat straw in the ratio of 2:1; IVDMD=In vitro dry matter digestibility; IVOMD=In vitro organic matter digestibility; ME=Metabolizable energy.

Table.4 Effect of level of Phalaris minor seeds replacing maize grains on in vitro ruminal fermentation pattern of total mixed rations

\begin{tabular}{|c|c|c|c|c|c|c|}
\hline TMR & $\begin{array}{l}\text { Level of } P \text {. minor seeds } \\
\text { in concentrate mixture } \\
\qquad(\%)\end{array}$ & $\begin{array}{c}\text { TVFA } \\
(\mathrm{meq} / 100 \mathrm{ml} \\
\text { incubation media) }\end{array}$ & $\begin{array}{l}\mathrm{NH}_{3}-\mathrm{N}(\mathrm{mg} / 100 \mathrm{ml} \\
\text { incubation media) }\end{array}$ & \multicolumn{3}{|c|}{ IVFA (molar \%) } \\
\hline TMR-1 & 0 & $7.20 \pm 0.15$ & $15.09 \pm 0.97$ & $69.32 \pm 0.86$ & $22.02 \pm 0.75$ & $8.65 \pm 0.40$ \\
\hline TMR-2 & 25 & $6.97 \pm 0.10$ & $15.36 \pm 0.09$ & $69.54 \pm 0.77$ & $21.71 \pm 0.71$ & $8.75 \pm 0.20$ \\
\hline TMR-5 & 100 & $6.63 \pm 0.07$ & $15.87 \pm 0.24$ & $70.53 \pm 0.30$ & $20.31 \pm 0.15$ & $9.16 \pm 0.33$ \\
\hline
\end{tabular}

Means bearing different superscripts in a column differ significantly $(\mathrm{P}<0.05)$;VFA=Total volatile fatty acids; $\mathrm{NH}_{3}-\mathrm{N}=\mathrm{Ammonia}-\mathrm{N}$; IVFA=Individual volatile fatty acids. 
However, there was no difference in methane production among TMR 2, TMR 3 and TMR 4 containing concentrate mixtures with 25,50 and 75 per cent $P$. minor seeds replacing maize grains, respectively. The results of the present study corroborate well with those of Ahmed (2013) who reported similar range of methane production from TMRs containing roughage to concentrate ratio of 60:40.

\section{Nutrient digestibility}

The in vitro DM digestibility was not affected on replacing cereal grains with $P$. minor seeds up to 75 per cent level in the concentrate mixture (Table 3). However, beyond that level, in vitro DM digestibility was depressed $(\mathrm{P}<0.05)$ when maize grains were completely replaced with $P$. minor seeds. The in vitro OM digestibility of TMRs also followed a similar trend to that of DM digestibility. The OM digestibility of TMR 2, TMR 3 and TMR 4 (25, 50 and 75 per cent $P$. minor seeds in the concentrate mixture, respectively) was comparable with that of TMR 1(without $P$. minor), but it was depressed $(\mathrm{P}<0.05)$ in $\mathrm{TMR}$ 5 having maize grains completely replaced with $P$. minor seeds. The data conclusively revealed that maize grains could be replaced by $P$. minor seeds up to 75 per cent in the diet without affecting the digestibility of nutrients. The findings of the current in vitro study of TMRs are also in good agreement with Kaur et al., (2006) who reported similar trend in the digestibility of nutrients on replacing cereal grains by $P$. minor seeds.

\section{In vitro fermentation characteristics}

In vitro fermentation characteristics revealed that the total volatile fatty acid (TVFA) production ranged from 6.63 in TMR 5 to 7.20 in TMR 1 (Table 4). The TVFA production showed a declining trend with increasing level of $P$. minor seeds, however, the decrease was statistically non-significant.
The results are in line with those of Kaur et al., (2006a, 2009) who carried out rumen studies in adult rumen fistulated male buffaloes fed TMRs containing different concentrate mixtures with graded levels of $P$. minor seeds. They reported that replacement of wheat grains by $P$. minor seeds up to $75 \%$ in concentrate mixture as well as inclusion of higher levels of $P$. minor seeds up to $60 \%$ in the concentrate mixture, showed no adverse effect on the TVFA concentration in the rumen. The TVFA levels in the present study were within the normal range as reported by Khan et al., (2015) who carried out in vitro evaluation of TMRs having roughage to concentrate ratio of 60:40. However, the values of TVFAs in the present study were lower than those reported by Ahmed (2013) from TMRs with roughage to concentrate mixed in the ratio of 60:40. The difference may be because of the different green fodder used and also due to the variation in the ingredient composition of the concentrate mixture used for formulation of TMR.

The $\mathrm{NH}_{3}-\mathrm{N}$ levels $(\mathrm{mg} / 100 \mathrm{ml})$ ranged from 15.09 (TMR 1) to 15.87 (TMR 5) (Table 4). The $\mathrm{NH}_{3}-\mathrm{N}$ showed an increasing trend with increasing level of $P$. minor seeds in the TMR. The reason may be the higher $\mathrm{CP}$ content of $P$. minor seeds as compared to that of maize grains. However, the difference in $\mathrm{NH}_{3}-\mathrm{N}$ production amongst various TMRs was statistically non-significant.

The results of the present study corroborate well with the findings of Kaur et al., (2009) who studied the effect of TMRs containing concentrate mixtures with $0,30,40,50$ and 60 per cent $P$. minor seeds on the biochemical changes in the rumen of fistulated male buffaloes. They reported that the $\mathrm{NH}_{3}-\mathrm{N}$ was higher $(\mathrm{P}<0.05)$ in the rumen liquor of the buffaloes fed $P$. minor seeds as compared to that in control group. The $\mathrm{NH}_{3}-\mathrm{N}$ production, in the present study, is within the normal 
range as reported Khan et al., (2015) for TMRs having roughage to concentrate ratio of 60:40.

The relative proportion of in vitro individual VFAs (acetate, propionate and butyrate) produced (molar \% of TVFA) on the fermentation of TMR 1 (without $P$. minor) was compared with other TMRs containing graded levels of $P$. minor seeds. The molar percentage of acetate ranged from $69.32 \%$ in TMR 1 (without $P$. minor) to $70.53 \%$ in TMR 5 (containing concentrate mixture with maize grains completely replaced by $P$. minor seeds). The molar percentage of butyrate ranged from $8.65 \%$ in TMR 1 to $9.16 \%$ in TMR5.

Though statistically non-significant, both acetate and butyrate exhibited an increasing trend, with increasing level of $P$. minor seeds in the concentrate mixture. This increase may be because of comparatively higher fibre content of $P$. minor seeds as compared to that of maize grains.

The molar percentage of propionate followed a reverse trend with higher production (22.02\%) from TMR 1 (without $P$. minor) and lower $(20.31 \%)$ from TMR 5 (maize grains completely replaced with $P$. minor seeds). However, no significant difference was observed in the relative proportion of acetate, propionate and butyrate amongst the TMRs evaluated.

The results conclusively revealed that $P$. minor seeds can be safely used as a replacement of maize grains up to 75 percent in the diet without any adverse effect on the in vitro nutrient digestibility and rumen fermentation pattern.

\section{Conflict of interest}

The authors declare no conflict of interest.

\section{References}

Ahmed, H.A., 2013. Propionic acid producing bacteria as direct fed microbial for growing cattle. Ph.D. Thesis, National Dairy Research Institute (Deemed University). Karnal. India.

AOAC, 2005. Official Methods of Analysis. $18^{\text {th }}$ edition. Association of Official Analytical Chemists, Arlington, Virginia, USA.

Barnett, A.J.G., Reid, R.L. 1957. Studies on the production of volatile fatty acids from grass in an artificial rumen. I. Volatile fatty acid production from fresh grass. J. Agr. Sci., 48: 315-321.

Gupta, B.K., Chopra, A.K., Shingari, B.K. 1989. Comparison of chemical composition of gullidanda (Phalaris minor) and maize seeds. Indian J. Anim. Nutr., 6: 262-64.

ICAR, 2013. Nutrient requirements of cattle and buffalo. Indian Council of Agricultural Research, New Delhi, India.

Kamble, A.B., Kundu, S.S., Shelke, S.K., Datt, C., Jha, Nisha. 2010. Evaluation of concentrate feedstuffs for carbohydrate and protein fraction and in vitro methane production. Indian J. Anim. Nutr., 27(2): 109-115.

Kaur, J., Kaushal, S., Pannu, M.S., Wadhwa, M., Bakshi, M.P.S. 2006a. Phalaris minor seeds-substitute of wheat grains in the diet of buffaloes. Indian J. Anim. Nutr., 23:67-71.

Kaur, J., Pannu, M.S., Kaushal, S., Wadhwa, M., Bakshi, M.P.S. 2006. In vitro evaluation of Phalaris minor seeds as livestock feed. Asian-Aust. J. Anim. Sci., 19: 363-67.

Kaur, J., Thakur, S.S. 2016. Characterization of carbohydrates and proteins in Phalaris minor seeds by Cornell net carbohydrate and protein system. Curr. Sci., 110 (7):1324-1329. 
Kaur, J., Wadhwa, M., Pannu, M.S., Bakshi, M.P.S. 2009. Effect of graded levels of Phalaris minor seeds on the nutrient utilization in buffaloes. Indian J. Anim Nutr., 26: 17-22.

Khan, N., Kewalramani, N., Chaurasia, M., Singh, S., Haq, Z. 2015.Effect of niacin supplementation on in-vitro rumen fermentation pattern in crossbred cattle. J. Anim. Res., 5: 479-483.

Lamba, J.S., Wadhwa, M., Bakshi, M.P.S. 2014.In vitro methane production potential and in sacco degradability of energy feeds. Indian J. Anim Nutr., 31(2): 131-137.

Menke, K.H., Raab, L., Salewski, A., Steingass, H., Fritz, D., Schneider W. 1979. The estimation of the digestibility and metabolizable energy content of ruminant feedstuffs from the gas production when they are incubated with rumen liquor. J. Agric. Sci., 93: 217-222.

Menke, K.H., Steingass, H. 1988. Estimation of the energetic feed value obtained from chemical analysis and in vitro gas production using rumen fluid. Anim. Res. Dev., 28: 7-55.

Patil, G.S., 2017.With pastures for cattle shrinking, India may have to import milk by 2021. http://www.hindustan times com/india-news/with-pastures-for-cattleshrinking-india-may-have-to-import-milkby-2021/story.html.

Ranjhan, S.K., 1998. Nutrient requirements of livestock and poultry. Indian Council of Agricultural Research (ICAR) Publication, New Delhi, India.

SAS, 2003. SAS User's Guide. Statistics (version 9.1) SAS Institute, Inc., Cary, New York, USA.

Van Soest, P. J., Robertson, J. B. and Lewis, B. A. 1991. Methods for dietary fiber, neutral detergent fiber and non starch polysaccharides in relation to animal nutrition. J. Dairy Sci., 74: 3583-3597.

\section{How to cite this article:}

Jasmine Kaur and Sudarshan Singh Thakur. 2017. In Vitro Methane Production Potential, Nutrient Digestibility and Fermentation Pattern of Total Mixed Rations containing Incremental Levels of Novel Feedstuff - Phalaris minor Seeds in Buffalo Inoculum. Int.J.Curr.Microbiol.App.Sci. 6(9): 96-103. doi: https://doi.org/10.20546/ijcmas.2017.609.011 